\title{
STRESS DURING PUBERTY FACILITATES PRECANCEROUS PROSTATE LESIONS IN ADULT RATS
}

\author{
D. Herrera-Covarrubias ${ }^{1,2, *}$, G.A. Coria-Avila ${ }^{2}$, M.E. Hernandez ${ }^{2}$, N. Ismail ${ }^{1}$ \\ ${ }^{1}$ School of Psychology, University of Ottawa, Ottawa K1N 6N5, ON, Canada \\ ${ }^{2}$ Centro de Investigaciones Cerebrales, Universidad Veracruzana, Xalapa 91193, VER, Mexico
}

\begin{abstract}
Puberty can be a critical period for the long-term development of diseases, especially for stress-related disorders that depend on neuroendocrine and immune responses. Some organs like the prostate are prone to diseases that result from neuroendocrine or immune challenges, such as cancer. Aim: In the present study, we assessed the long-term effects of an acute pubertal stressor (immune-challenge) on the development of precancerous lesions in adult rats, and compared them with testosterone-induced prostatic lesions. Materials and Methods: Pubertal male rats received a single injection of lipopolysaccharide (LPS) or saline during puberty (5 weeks old). At adulthood (8 weeks old) males were subcutaneously implanted with either an empty capsule or filled with testosterone propionate $(100 \mathrm{mg} / \mathrm{kg})$. This resulted in a total of five groups: 1) intact untreated, 2) saline-treated and implanted with a blank capsule, 3) saline-treated and implanted with a testosterone capsule, 4) LPS-treated and implanted with a blank capsule, 5) LPS-treated and implanted with a testosterone capsule. Four weeks later, the rats were sacrified and their prostates processed for histology (hematoxylin and eosin stain) and blood serum processed for hormone analysis (testosterone and corticosterone). Results: Males treated with LPS (stressed during puberty via immune challenge) expressed epithelium dysplasia (specially in the ventral prostate), anisocytosis, presence of mononuclear cells, anisokariosis, non-basal polarity, abnormal nucleus-cytoplasm ratio, proplastic myoepithelium, and granular content in the lumen. These histological alterations were similar, but less severe than those observed in males implanted with testosterone during adulthood. Conclusion: These results indicate that pubertal exposure to an immune challenge (stress) facilitates the long-term development of prostatic lesions in adult male rats.
\end{abstract}

Key Words: prostate, cancer, stress, puberty, testosterone, LPS.

The prostate is an exocrine reproductive gland prone to different types of diseases such as inflammation (prostatitis), progressive enlargement (benign prostatic hyperplasia, $\mathrm{BPH}$ ), and prostate cancer (CaP). The risk of $\mathrm{CaP}$ involves many environmental and hereditary factors such as unhealthy diet, obesity, older age, African ancestry and atypical sexual hormonal milieu [1-6]. Precancerous lesions (e.g. epithelium dysplasia, anisocytosis, anisokaryosis, apolarity, etc.) have been reported in individuals with a previous history of prostatic chronic inflammation due to infections [7], and in experimental animals that undergo constant copulation [8], or in those treated with systemic testosterone $[9,10]$ or prolactin $[6$, 11]. Accordingly, the risk for development of $\mathrm{CaP}$ is higher when the prostate is exposed to hormonal and immune challenges, especially in individuals at susceptible age, with genetic predisposition and unhealthy diets.

Some studies indicate that puberty should be considered a critical period for the long-term develop-

Submitted: May 9, 2017.

*Correspondence: E-mail: dherrera.covarrubias@gmail.com Abbreviations used: ACTH - adrenocorticotropic hormone; ANOVA - analysis of variance; AR - androgen receptor; $\mathrm{BPH}-$ benign prostatic hyperplasia; $\mathrm{CaP}$ - prostate cancer; COX2 cyclooxygenase 2; CR - corticosterone receptor; DLP - dorsolateral prostate; ELISA - enzime-linked immunosorbent assay; $\mathrm{H} \& \mathrm{E}$ - hematoxylin and eosin; HPA - hypothalamic-pituitaryadrenal; HPG - hypothalamic-pituitary-gonadal; IL - interleukin; IFN - interferon; i.p. - intraperitoneal; LPS - lipopolysaccharide; mRNA - messenger RNA; N:C - nucleus:cytoplasm; MNU -

$\mathrm{N}$-nitroso-N-methylurea; NF-KB - nuclear factor kappa light chain enhancer of activated B cells; PGE2 - prostaglandin E2; PRL prolactin; s.c. - subcutaneous; TNF - tumor necrosis factor; VP ventral prostate. ment of diseases, especially for those that depend on neuroendocrine and immune responses, perhaps because during puberty the hypothalamic-pituitaryadrenal (HPA) axis is more responsive to stressors than in adulthood [12]. For instance, as compared to adults, pubertal male rats exposed to acute restraint stress (30 min) express longer peaks of adrenocorticotropic hormone (ACTH) and corticosterone. In addition, after chronic restraint stress (30 min daily) pubertal rats express higher peaks that return faster to baseline levels [13]. Similarly, the serum levels of testosterone [14] and prolactin [15] increase more in pubertal rats than in adults after chronic stress. Higher or longer hormonal responses during pubertal stress may result in enduring changes in hormone-sensitive organs, increasing the susceptibility to severe diseases like CaP.

Some studies in laboratory mice have used the bacterial endotoxin lipopolysaccharide (LPS) to induce a stress-like and immune response that induces the display of sickness symptoms for about two days or less [16-18]. LPS is a component of the cellular membrane of gram-negative bacteria. Treatment with LPS results in the production of cytokines, cyclooxygenase 2 (COX-2), and prostaglandins (PGE2) among other molecules [18] which can activate the HPA axis. In mice, treatment with LPS at 6 weeks of age (puberty) results in permanent neuroendocrine alterations. For example, pubertal females that receive LPS display reduced sexual receptivity in adulthood. This does not occur if LPS is injected during the postnatal weeks 3 , 7,8 or 10 [19], indicating that the long-term effects of LPS treatment occur exclusively when it is experienced during the pubertal stress sensitive period 
(5-6 weeks old). Moreover, mice treated with LPS at 6 weeks of age display altered behavioral responsiveness to estradiol for anxiety-like and depressionlike behaviors and cognitive functioning. These findings suggest that pubertal treatment globally alters the behavioral responsiveness to estradiol (and probably to other hormones) by affecting both reproductive and non-reproductive behaviors [20-22].

Thus, in the present study, we tested the effects of pubertal stress on precancerous prostatic lesions and levels of hormones known to modulate prostate histology and stress. Our first hypothesis stated that pubertal treatment with LPS would induce histological prostatic lesions in adulthood comparable to the lesions observed in males exposed to exogenous systemic testosterone (a positive control for precancerous lesions). In addition, we hypothesized that the baseline blood levels of testosterone and corticosterone would be higher in adult males that received LPS during puberty.

\section{MATERIALS AND METHODS}

Animals. Forty Wistar male rats (Rattus norvegicus albinus) were purchased and shipped at 4 weeks of age from a certified laboratory animal supplier in Mexico (Circulo ADN ${ }^{\circledR}$ ). They were housed in groups of five rats in large Plexiglas cages $(50 \times 30 \times 20 \mathrm{~cm})$ and kept in a colony room at the Centro de Investigaciones Cerebrales, Universidad Veracruzana, Mexico, in a $12-12 \mathrm{~h}$ reverse Light-Dark cycle (lights off at 8:00 h). Water and commercial rat chow (RismartOे) were provided ad libitum. All the experimental procedures were carried out according to the Official Mexican Norm for use and care of laboratory animals (NOM-062-ZOO-1999) [23] and the International Guiding Principles for Biomedical Research [24].

Groups and treatments. The rats were randomly assigned to one of the following five groups: 1 ) intact $(n=8), 2)$ saline-blank $(n=8), 3)$ saline-testosterone $(n=8), 4)$ LPS-blank ( $n=8), 5)$ LPS-testosterone $(n=8)$. Table 1 indicates treatment for each group and the age (weeks) at the time of treatment. At 5 weeks of age, rats from groups 4 and 5 received one intraperitoneal (i.p.) injection of LPS (LPS from E. coli, Sigma-Aldrich) at a dose of $1.5 \mathrm{mg} / \mathrm{kg}$ in a volume of $1 \mathrm{ml} / \mathrm{kg}$ of sterile saline. Groups 2 and 3 received exclusively a saline injection (i.p.) and group 1 received no treatment. Rats were monitored at 2, 4, 8, 24 and $48 \mathrm{~h}$ following the injection to detect the presence of five sickness symptoms (ptosis, piloerection, lethargy, huddling) as previously reported [18], and the posture of kyphosis. Such period is sufficient to detect whether or not rats respond to LPS. At each time-point, rats were given a score from 0 to 5 , depending on the number of symptoms observed (Fig. 1). During the following three weeks, the rats were handled daily, and their general health was monitored. At 8 weeks of age, groups 3 and 5 were implanted subcutaneously (s.c.) with a silastic tube filled with testosterone (Sigma-Aldrich Mexico catalogue 1649007), whereas groups 2 and 4 were implanted with a blank (empty) capsule. Group 1 re- ceived no treatment. The silastic tube (Dow Corning CorpÒ $25 \mathrm{~mm}$ length, $1.57 \mathrm{~mm}$ I.D. $\times 3.18 \mathrm{~mm}$ O.D.) contained powdered testosterone propionate (SigmaAldrich química, Mexico). This resulted in approximately $100 \mathrm{mg} / \mathrm{kg}$ of body weight as previously used in other studies $[8,11,25]$. Surgical implantation of the tube was done under inhaled galothane anesthesia, and took less than 3 min for each rat. A detailed description of the procedure can be found in our previously published paper [8]. After confirmation of deep anesthesia, we performed a $10 \mathrm{~mm}$ skin incision on the lower back. A surgical probe was used to separate the skin from the muscle. The silastic tube was inserted under the skin and pushed rostrally until placed s.c. in the upper back, between the two scapulae. The lower back incision was sutured and the rat was allowed to fully recover before it was placed back into its home cage. Early studies showed that these silastic capsules release testosterone at a rate of $\sim 30 \mu \mathrm{g} / \mathrm{day} / \mathrm{cm}$ [26].

Table 1. Groups and treatments

\begin{tabular}{lccc}
\hline & \multicolumn{3}{c}{ Treatment } \\
\cline { 2 - 4 } \multicolumn{1}{c}{ Group } & $\begin{array}{c}\text { 5 weeks } \\
\text { single intrape- } \\
\text { ritoneal (i.p.) } \\
\text { injection }\end{array}$ & $\begin{array}{c}\text { 8 weeks } \\
\text { subcutane- } \\
\text { ous (s.c.) } \\
\text { implant }\end{array}$ & 12 weeks \\
\hline (1) Intact & nothing & nothing & histopathology \\
(2) Saline-blank & saline & empty & histopathology \\
(3) Saline-testosterone & saline & testosterone & histopathology \\
(4) LPS-blank & LPS & empty & histopathology \\
(5) LPS-testosterone & LPS & testosterone & histopathology \\
\hline
\end{tabular}

Note: At 5 weeks of age (puberty) male rats received an i.p. injection of either LPS $(1.5 \mathrm{mg} / \mathrm{kg} / \mathrm{ml})$, saline $(1 \mathrm{ml} / \mathrm{kg})$ or nothing. At 8 weeks of age (adulthood) the same rats received a s.c. implant filled with testosterone, empty, or remained untreated. At 12 weeks of age all the males were sacrificed and their prostates processed for histology.

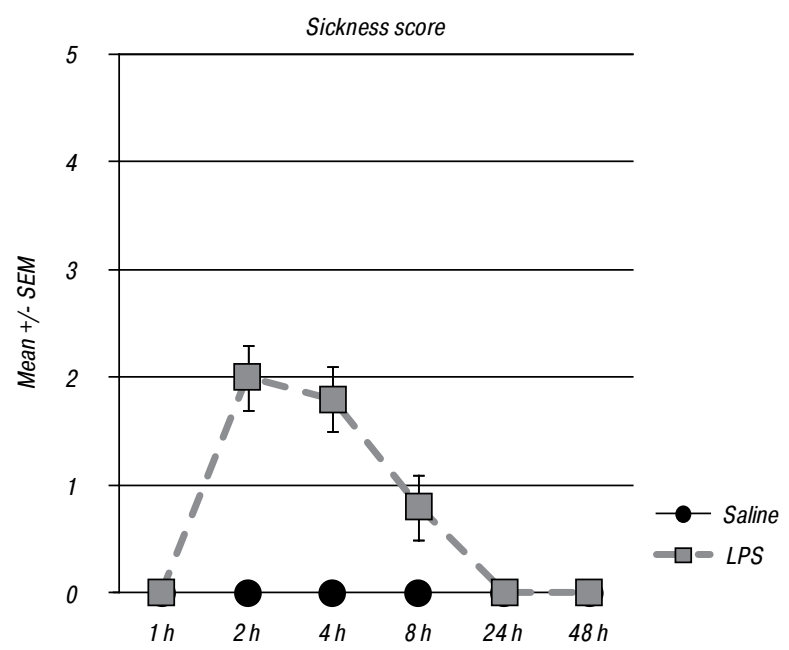

Fig. 1. Sickness scores in male rats treated either with saline or LPS during puberty (5 week old)

Prostate samples and histology. At 12 weeks of age the rats were deeply anesthetized with sodium pentobarbital (60 mg $/ \mathrm{kg}$ i.p.). Then, $3 \mathrm{ml}$ of blood were obtained by cardiac puncture for hormone analysis (see Hormone measurements for further details). After blood sampling rats were sacrificed with an overdose of sodium pentobarbital (120 mg/kg i.p.). An abdominal incision was performed and the accessory sexual organs were carefully removed and placed into a container with $0.9 \%$ 
saline solution. The prostate was identified under a dissecting microscope (MEJI, EMZ-TRÒ) and divided into ventral (VP) and dorsolateral (DLP) prostate. As in our previous studies $[8,11]$ the VP and DLP were soaked in $10 \%$ formalin for $24 \mathrm{~h}$, then dehydrated in $70 \%$ and $80 \%$ alcohol ( 1 h each), and 95\% ( $3 \times 2$ h each), and 100\% ethanol overnight, plus two more changes ( $1 \mathrm{~h}$ each), the following day. Then xylene ( $3 \times 1 \mathrm{~h}$ each), always in constant shaking. Tissue was embedded in paraffin wax ( $2 \times 2 \mathrm{~h}$ each), sliced ( $5 \mu \mathrm{m}$ thick) with a microtome (RM 2125RT Leica, Germany), mounted on slides in a bath at $52{ }^{\circ} \mathrm{C}$ (containing pork skin-based gelatin $2.5 \mathrm{mg} / 100 \mathrm{ml}$ ) and then processed for hematoxylin and eosin (H \& E) dye technique as follows: $1 \mathrm{~h}$ at $57^{\circ} \mathrm{C}$, deparaffinization in xylene ( $3 \times 5$ min each), rehydrated in alcohol/xylene (1:1) $5 \mathrm{~min}$, ethanol $96 \% 3 \mathrm{~min}$, hematoxylin (10 min), water (30 s), acid alcohol (quick immersion), water (10 s), lithium carbonate (30 s), water (10 s), eosin (4 quick immersions). Dehydration in ethanol 96\% (3 min), ethanol 100\% ( $2 \mathrm{~min}$ ), ethanol/xylene 1:1 (2 $\mathrm{min})$, and xylene ( $5 \mathrm{~min}$ ). Then, the slides were coverslipped with Permount (SP15-500 Fisher chemicals), air dried, and observed under a light microscope (Olympus Ax70, Japan). Photomicrographs were taken at $40 \times$ and analyzed by the same experimenters. As formerly reported, we assessed prostate histology by taking into consideration 12 histological features (Table 2) [8, 11]. Experimenters were blind to the treatment at the time of diagnosis.

Hormones measurement. Concentrations of testosterone and corticosterone in blood serum were measured at one single time point at 12 weeks of age, at the time of prostate extraction. Blood was collected in vacutainer tubes containing no anticoagulant and incubated in upright position at room temperature for $30 \mathrm{~min}$ to allow clotting. Tubes were centrifuged for $15 \mathrm{~min}$ at $1000 \mathrm{rpm}$. Supernatant was aspirated at room temperature and serum was kept in $500 \mathrm{ml}$ aliquots and frozen at $-20^{\circ} \mathrm{C}$ for a few days until processing. Hormones levels were quantified using enzyme-linked immunosorbent assay (ELISA) and commercial kits for testosterone (ALPCO, USA) and corticosterone (ALPCO, USA). The procedure was carried out as instructed by the supplier. The assays were read in an IMARK microplate reader with the software microplate manager from Bio-Rad.

Variables and statistical analysis. Sickness score: We examined the intensity $(0-5)$ and duration $(0-48 \mathrm{~h})$ of sickness after treatment with LPS during puberty. The number of rats expressing symptoms at each time point were recorded. Histology: Twelve histological features were analized in each male in adulthood (see Table 2). Tables 3 and 4 indicate histological results observed in at least 6 out of 8 males for group. Hormones: Levels of testosterone and corticosterone $(\mathrm{ng} / \mathrm{ml})$ in adulthood were analyzed with a one-way analysis of variance (ANOVA), followed by a Fisher LSD post hoc test to compare individual differences. All statistical analyses were performed using GraphPad Prism version 6.00 for Mac, GraphPad Software, La Jolla
California USA, www.graphpad.com and the alpha level was set at $p<0.05$.

\section{RESULTS}

Sickness score during puberty. Of the 16 rats that received LPS during puberty, only two failed to express any sickness symptom. The most common symptom was lethargy (68\%), followed by kyphosis $(50 \%)$, ptosis $(38 \%)$, huddling $(38 \%)$ and piloerection (13\%). None of the males from the saline group expressed symptoms after injection. Fig. 1 depicts the sickness score, indicating that a maximum peak response occurred $2 \mathrm{~h}$ after injection and lasted for less than $24 \mathrm{~h}$.

Table 2. Characterization of both normal (expected) and abnormal (non-expected) histology in the prostate of adult rats

\begin{tabular}{|c|c|c|c|}
\hline Histological feature & Region & $\begin{array}{c}\text { Normal } \\
\text { (expected cases) }\end{array}$ & $\begin{array}{c}\text { Abnormal } \\
\text { (non-expected } \\
\text { cases) }\end{array}$ \\
\hline Epithelium form & $\begin{array}{l}\text { DLP } \\
\text { VP }\end{array}$ & $\begin{array}{c}\text { cubic } \\
\text { columnar }\end{array}$ & $\begin{array}{c}\text { metaplasia, } \\
\text { dysplasia }\end{array}$ \\
\hline Epithelium size & $\begin{array}{l}\text { DLP } \\
\text { VP }\end{array}$ & even & anisocytosis \\
\hline Epithelium papillae & $\begin{array}{l}\text { DLP } \\
\text { VP }\end{array}$ & scarce & plenty \\
\hline Interstice space & $\begin{array}{l}\text { DLP } \\
\text { VP }\end{array}$ & even & compressed \\
\hline Interstice content & $\begin{array}{l}\text { DLP } \\
\text { VP }\end{array}$ & collagen & mononuclear \\
\hline Nucleus size & $\begin{array}{l}\text { DLP } \\
\text { VP }\end{array}$ & even & anisokariosis \\
\hline Nucleus location & $\begin{array}{l}\text { DLP } \\
\text { VP }\end{array}$ & basal cell polarity & non-polar \\
\hline Nucleus-cytoplasm ratio & $\begin{array}{l}\text { DLP } \\
\text { VP }\end{array}$ & $1: 3$ & $<1: 3$ \\
\hline Myoepithelium & $\begin{array}{l}\text { DLP } \\
\text { VP }\end{array}$ & euplasia & proplasia \\
\hline Pattern (at $4 \times$ ) & $\begin{array}{l}\text { DLP } \\
\text { VP }\end{array}$ & tubular & cribiform \\
\hline Lumen content & $\begin{array}{l}\text { DLP } \\
\text { VP }\end{array}$ & amorphous & granular \\
\hline Chromatin & $\begin{array}{l}\text { DLP } \\
\text { VP }\end{array}$ & heterochromatin & euchromatin \\
\hline
\end{tabular}

Note: Normal features were inferred from the number of cases observed in groups 1 (intact) and 2 (saline-blank) of the present study.

Table 3. Histological features of the VP of males from the different groups. Features were accepted when it was observed in at least 6 out of 8 males

\begin{tabular}{|c|c|c|c|c|c|}
\hline \multirow[b]{2}{*}{ Histology } & \multicolumn{5}{|c|}{ Ventral prostate } \\
\hline & Intact & $\begin{array}{l}\text { Saline } \\
\text { blank }\end{array}$ & $\begin{array}{c}\text { Saline } \\
\text { testoste- } \\
\text { rone }\end{array}$ & $\begin{array}{l}\text { LPS } \\
\text { blank }\end{array}$ & $\begin{array}{l}\text { LPS } \\
\text { testoste- } \\
\text { rone }\end{array}$ \\
\hline Epithelium & & & & & \\
\hline Form & columnar & columnar & dysplasia & dysplasia & dysplasia \\
\hline Size & anisocy- & even & anisocy- & anisocy- & anisocy- \\
\hline $\begin{array}{l}\text { Papillae } \\
\text { Interstice }\end{array}$ & plenty & plenty & plenty & plenty & plenty \\
\hline Space & even & even & even & even & even \\
\hline $\begin{array}{l}\text { Content } \\
\text { Nucleus }\end{array}$ & collagen & collagen & collagen & collagen $^{3}$ & collagen \\
\hline Size & even ${ }^{1}$ & even ${ }^{1}$ & $\begin{array}{c}\text { anisoka- } \\
\text { ryosis }\end{array}$ & $\begin{array}{c}\text { anisokary- } \\
\text { osis }\end{array}$ & $\begin{array}{c}\text { anisoka- } \\
\text { ryosis }\end{array}$ \\
\hline Location & polar & polar & no polar & polar & no polar \\
\hline $\begin{array}{l}\text { Nucleus: } \\
\text { cytoplasm }\end{array}$ & $>1: 3$ & $>1: 3$ & $1: 1$ & $1: 1$ & $1: 1$ \\
\hline Myoepithelim & euplasia & euplasia & proplasia & euplasia & proplasia \\
\hline Pattern $(4 \times)$ & tubular & tubular & tubular & tubular & tubular \\
\hline $\begin{array}{l}\text { Lumen } \\
\text { content }\end{array}$ & $\begin{array}{l}\text { amor- } \\
\text { phous }\end{array}$ & amorphous & amorphous & $\begin{array}{l}\text { amour- } \\
\text { phous }\end{array}$ & amorphous \\
\hline Chromatin & $\begin{array}{l}\text { hetero- } \\
\text { chrom }^{2}\end{array}$ & $\begin{array}{l}\text { hetero- } \\
\text { chrom }^{2}\end{array}$ & $\begin{array}{l}\text { hetero- } \\
\text { chrom² }^{2}\end{array}$ & $\begin{array}{l}\text { hetero- } \\
\text { chrom }^{2}\end{array}$ & $\begin{array}{l}\text { hetero- } \\
\text { chrom² }^{2}\end{array}$ \\
\hline
\end{tabular}

Notes: ${ }^{1}$ some cases may express anisokaryosis; ${ }^{2}$ some cases may express euchromatin; ${ }^{3}$ some cases may express mononuclear content. 
Table 4. Histological features of the DLP of males from the different groups. Features were accepted when it was observed in at least 6 out of 8 males

\begin{tabular}{|c|c|c|c|c|c|}
\hline \multirow[b]{2}{*}{ Histology } & \multicolumn{5}{|c|}{ Dorsolateral prostate } \\
\hline & Intact & $\begin{array}{l}\text { Saline } \\
\text { blank }\end{array}$ & $\begin{array}{c}\text { Saline } \\
\text { testosterone }\end{array}$ & $\begin{array}{c}\text { LPS } \\
\text { blank }\end{array}$ & $\begin{array}{c}\text { LPS } \\
\text { testosterone }\end{array}$ \\
\hline \multicolumn{6}{|l|}{ Epithelium } \\
\hline Form & cubic & cubic $^{4}$ & dysplasia & cubic $^{6}$ & dysplasia \\
\hline Size & even & even $^{5}$ & anisocytosis & anisocytosis & anisocytosis \\
\hline $\begin{array}{l}\text { Papillae } \\
\text { Interstice }\end{array}$ & scarce & scarce & moderate & moderate & plenty \\
\hline Space & even & even & even & even & even \\
\hline Content & collagen & collagen & collagen & $\begin{array}{l}\text { mononu- } \\
\text { clear }\end{array}$ & collagen \\
\hline \multicolumn{6}{|l|}{ Nucleus } \\
\hline Size & even $^{1}$ & even $^{1}$ & $\begin{array}{l}\text { anisokary- } \\
\text { osis }\end{array}$ & $\begin{array}{l}\text { anisokary- } \\
\text { osis }\end{array}$ & $\begin{array}{l}\text { anisokary- } \\
\text { osis }\end{array}$ \\
\hline Location & polar & polar & no polar & no polar & no polar \\
\hline $\begin{array}{l}\text { Nucleus: } \\
\text { cytoplasm }\end{array}$ & $>1: 3$ & $>1: 3$ & $1: 1$ & $1: 1$ & $1: 1$ \\
\hline $\begin{array}{l}\text { Myoepithe- } \\
\text { lium }\end{array}$ & euplasia $^{2}$ & euplasia $^{2}$ & proplasia & proplasia & proplasia \\
\hline Pattern $(4 \times)$ & tubular & tubular & tubular & tubular & tubular \\
\hline $\begin{array}{l}\text { Lumen } \\
\text { content }\end{array}$ & $\begin{array}{l}\text { amor- } \\
\text { phous }\end{array}$ & $\begin{array}{l}\text { amor- } \\
\text { phous }\end{array}$ & amorphous & granular & granular \\
\hline Chromatin & $\begin{array}{l}\text { hetero- } \\
\text { chrom }^{3}\end{array}$ & $\begin{array}{l}\text { hetero- } \\
\text { chrom }^{3}\end{array}$ & $\begin{array}{l}\text { hetero- } \\
\text { chrom }^{3}\end{array}$ & $\begin{array}{l}\text { hetero- } \\
\text { chrom }^{3}\end{array}$ & $\begin{array}{l}\text { hetero- } \\
\text { chrom }^{3}\end{array}$ \\
\hline
\end{tabular}

Notes: ${ }^{1}$ some cases express anisokariosis; ${ }^{2}$ some cases express proplasia; ${ }^{3}$ some cases express euchromatin; ${ }^{4}$ some cases express metaplasia;

${ }^{5}$ some cases express anisocytosis; ${ }^{6}$ some cases express dysplasia.

Prostate histology in adulthood. The results indicate that pubertal LPS treatment resulted in abnormal prostatic histology in adulthood (see Tables 3, 4, Fig. 2-4). For instance, there were more cases of epithelium dysplasia, specially in the VP (see Fig. 2, 3), but also anisocytosis, presence of mononuclear cells, anisokariosis, non-basal polarity, abnormal nucleuscytoplasm ratio, proplastic myoepithelium, and granular content in the lumen. These histological features are abnormal and can be considered precancerous.

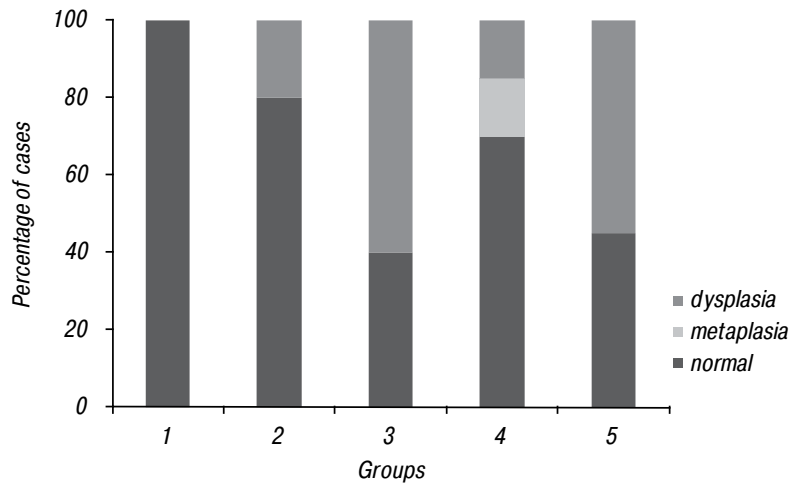

Fig. 2. Epithelium features in the DLP of male rats: 1 - intact untreated; 2 - saline-treated and implanted with a blank capsule in adulthood; 3 - saline-treated and implanted with a testosterone capsule; 4 - LPS-treated and implanted with a blank capsule; 5 - LPS-treated and implanted with a testosterone capsule. Histology was assessed with $\mathrm{H}$ \& E stain in order to identify precancerous lesions

Serum levels of testosterone and corticosterone. With regard to testosterone, the ANOVA revealed significant differences $\mathrm{F}(4,35)=3.5(p<0.01)$. The posthoc test indicated that serum from LPS-testosterone rats contained significantly higher testosterone levels $($ mean $=10.21 \mathrm{ng} / \mathrm{ml}$ ) than LPS-blank controls $($ mean $=7.3 \mathrm{ng} / \mathrm{ml})$. LPS-blank rats $($ mean $=7.2 \mathrm{ng} / \mathrm{ml})$ contained lower testosterone levels than saline-testosterone rats $($ mean $=11.05 \mathrm{ng} / \mathrm{ml})$. As expected, saline-

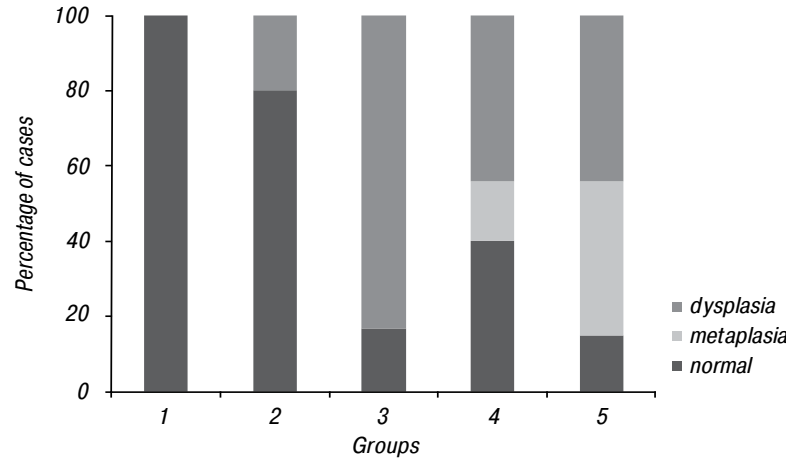

Fig. 3. Epithelium features in the VP of male rats: 1 - intact untreated; 2 - saline-treated and implanted with a blank capsule in adulthood; 3 - saline-treated and implanted with a testosterone capsule; 4 LPS-treated and implanted with a blank capsule; 5 - LPS-treated and implanted with a testosterone capsule. Histology was assessed with $\mathrm{H} \& \mathrm{E}$ stain in order to identify precancerous lesions
$D L P$
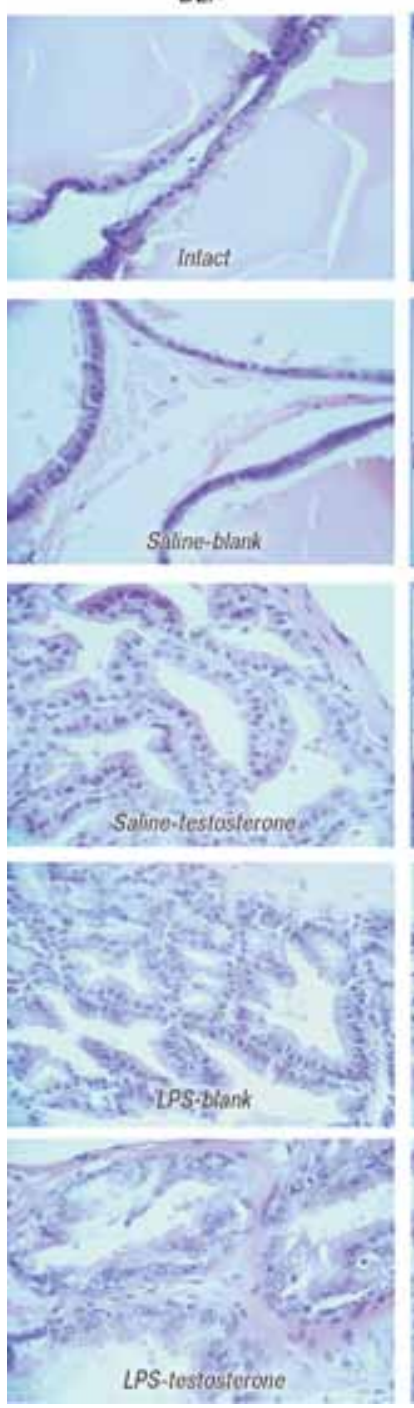

LPS-tostasterone
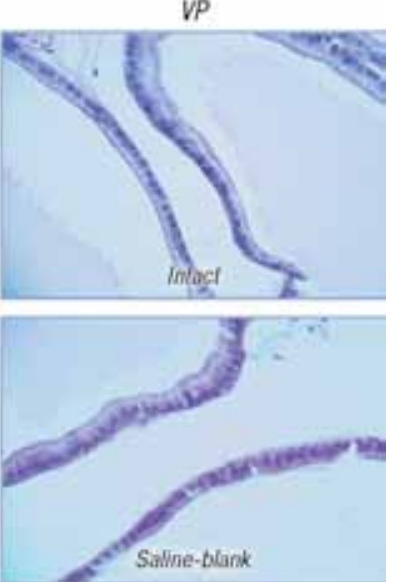
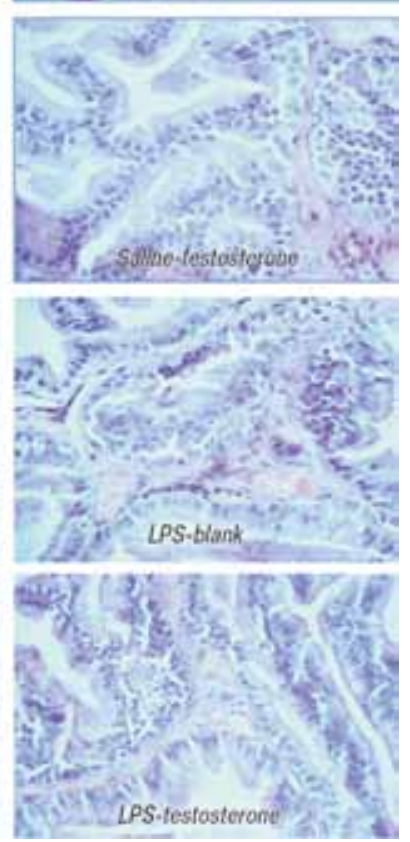

Fig. 4. Photomicrographs of the DLP and VP $(\times 40)$. Histological abnormalities are observed in treatments saline-testosterone, LPS-blank and LPS-testosterone. See Table 2 for details

testosterone rats $($ mean $=11.05 \mathrm{ng} / \mathrm{ml}$ ) contained higher testosterone levels than intact rats $($ mean $=8.5 \mathrm{ng} / \mathrm{ml}$ ) (Fig. 5). With regard to corticosterone, the analysis did not to detect significant differences between groups $F(4,35)=0.37(p>0.05)$ (Fig. 6) . 


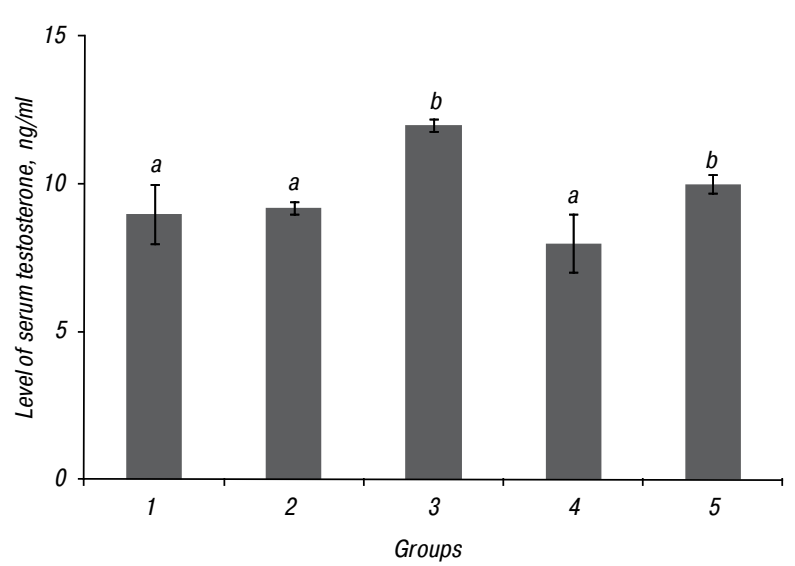

Fig. 5. Mean \pm S.E.M of baseline serum levels of testosterone in the different groups: 1 - intact untreated; 2 - saline-treated and implanted with a blank capsule in adulthood; 3 - salinetreated and implanted with a testosterone capsule; 4 - LPStreated and implanted with a blank capsule; 5 - LPS-treated and implanted with a testosterone capsule. Different letters indicate $p<0.05$

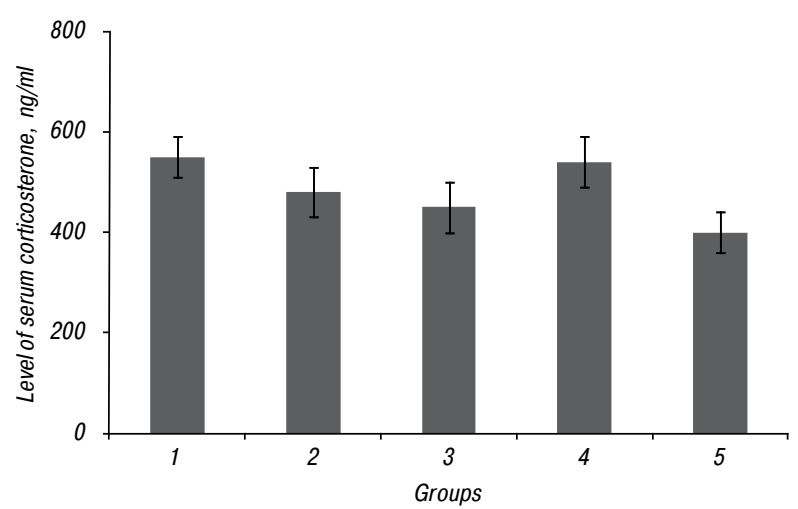

Fig. 6. Mean \pm S.E.M of baseline serum levels of corticosterone in the different groups: 1 - intact untreated; 2 - saline-treated and implanted with a blank capsule in adulthood; 3 - salinetreated and implanted with a testosterone capsule; 4 - LPStreated and implanted with a blank capsule; 5 - LPS-treated and implanted with a testosterone capsule

\section{DISCUSSION}

The results of the present study indicate that acute LPS treatment to pubertal rats ( 5 week old) results in long-term abnormal histological features of the prostate, observable in adulthood (12 weeks old). LPS-treated rats expressed more cases of epithelium dysplasia specially in the VP (see Fig. 2, 3), anisocytosis in DLP, presence of mononuclear cells in DLP and VP, anisokariosis in DLP and VP, non-basal polarity in DLP, abnormal nucleus-cytoplasm ratio in DLP and VP, proplastic myoepithelium in DLP and granular content in the lumen in DLP. Anisocytosis (unequal abnormal size of epithelium cells) and abnormal nuclear shape (anisokaryosis) can be used to identify cancerous cells $[27,28]$. Anysokaryosis, apolarity and abnormal nucleus-cytoplasm ratio denote changes in chromosome organization, and presumably affect gene expression [29] that may result in metaplasia or dysplasia; the latter considered the anteroom of CaP. When pubertal LPS was combined with testosterone in adulthood (LPS-testosterone group) the number of animals with prostatic lesions did not increase. Lesions on these animals were similar to those observed in the group that received testosterone only (saline-testosterone), suggesting that LPS during puberty has no additional effect than those caused by testosterone in adulthood, or vice versa. However, two males of the LPS-testosterone group failed to express sickness symptoms after the injection with LPS during puberty. Those males expressed normal (cubic) epithelium in the DLP, but dysplasia and stratified epithelium in the VP, respectively. They also expressed anisokaryosis and non-basal polarity. This might suggest a link between the susceptibility to express sickness after receiving LPS in pubertal animals and the probability to develop precancerous prostate lesions. Further research is needed to investigate this possible relationship.

LPS and endocrine alterations. Previous studies indicate that chronic stress (i.e. restraint) during puberty results in higher levels of serum testosterone [14], which is a hormone that can induce cell division and spontaneous mutations within the prostate $[9,10]$, and a confirmed cause of epithelium dysplasia [11]. Accordingly, we first hypothesized that acute immune stress during puberty (LPS-induced) would result in higher levels of testosterone in adulthood, with the corresponding prostatic lesions. However, the levels of serum testosterone increased exclusively in males with a testosterone implant (as expected), but not in animals that received one injection of LPS during puberty (LPS-blank) (see Fig. 5). Some reports indicate that the density of androgen receptors (AR) is modified in CaP or following an infection [30, 31]. We speculate about the possibility that LPS may alter the AR density, which would contribute to the gland's susceptibility to suffer spontaneous cell division or mutations under the effects of normal serum testosterone levels. AR gene can mutate or be amplified and therefore may respond to lower or equal levels of androgens in adulthood [6, 32-34]. Further research is needed to understand the longterm effects of pubertal LPS on the distribution and presence of $A R$ in the adult prostate.

Similarly, we hypothesized that corticosterone baseline serum levels would be higher in those adult males that received LPS during puberty as a consequence of enduring HPA axis activity enhancement. Indeed, other studies have shown that stress in adulthood facilitates the progression of different types of cancer [35-38]. For example, stressed rats (i.e. isolated) that receive a carcinogenic drug such as $\mathrm{N}$-methyl-N-nitrosurea (NMU) express higher levels of blood corticosterone and $30 \%$ more mammary tumors that express more corticosterone receptors $(\mathrm{CR})$ as compared to rats that only receive NMU without being stressed [35]. Our results, however, indicated that males from all the groups expressed similar serum levels of corticosterone in adulthood (see Fig. 6). Therefore, we consider that further research is needed to explore the effects of LPS on the distribution and proportion of $\mathrm{CR}$ in the prostate. 
Some reports indicate that treatment with LPS to neonatal rats results in immediate increase of corticosterone that does not correspond to adult response [39]. For example, in one study 5-day-old males were treated with LPS (from S. enterica) and $4 \mathrm{~h}$ later their levels of corticosterone were higher $(20 \mathrm{ng} / \mathrm{ml})$ than controls $(17 \mathrm{ng} / \mathrm{ml})$, but the levels of testosterone were lower $(0.1 \mathrm{ng} / \mathrm{ml})$ than controls $(0.4 \mathrm{ng} / \mathrm{ml})$. Interestingly, in adulthood, the levels of corticosterone were lower $(350 \mathrm{ng} / \mathrm{ml})$ than controls $(550 \mathrm{ng} / \mathrm{ml}$ ) following a stress challenge. LPS rats also expressed lower levels of testosterone ( $2 \mathrm{ng} / \mathrm{ml}$ ) than controls $(3 \mathrm{ng} / \mathrm{ml})$ [39]. These alterations correlated with the presence of abnormal testicular epithelium. Accordingly, LPS in neonatal rats affects epithelia and can alter the levels of testosterone and corticosterone in adulthood, but such alterations are observed only following a stress challenge.

Stress, inflammation and CaP. LPS increases the level of some cytokines such as IL-1b, IL-6, IL-10, IL-12 [18, 36], and also IFN- $\gamma$, TNF- $\alpha$ [18], and NF-kB [40] which results in subclinical inflammation. Inflammation is very common within the adult human prostate [7], and some studies have reported positive correlations between prostatitis and higher probability of developing CaP [41, 42]. In our study, LPS-treated males expressed more mononuclear cells than control animals seven weeks later (indicating subclinical and chronic inflammation). E. coli and Enterococcus spp. are the most common microorganisms causing prostatitis [43, 44], and mouse models of prostatitis following injections of $E$. coli also express epithelial proliferation and reactive hyperplasia, dysplasia and oxidative DNA damage $[45,46]$. Other organisms such as Pseudomonas spp., Proteus mirabilis, Klebsiella spp. and Serratia spp. have also been identified as a cause of prostatitis, all of them gram negative bacteria (LPS-holders).

Differential effects of LPS on DLP and VP. The two portions of the rat's prostate (DLP and VP) respond differently to experimental manipulations $[8,11]$. For instance, multiple trials of copulation result in histological alterations in the DLP, and the addition of exogenous testosterone results in even greater alterations [8]. However, in the VP copulation plus exogenous testosterone results in fewer cases of dysplasia. The VP expresses different proportion of AR and AR-mRNA [47] and such heterogeneity may account for the different effects observed following exogenous testosterone with repetitive copulation [8]. Interestingly, the results of the present study showed that LPS resulted in more cases of dysplasia in the VP.

\section{CONCLUSIONS}

Pubertal immune challenge results in histological alterations in the two prostatic portions (DLP, VP) in adult rats. These lesions can be considered precancerous, but are not cancer per se, and are likely to be reversible.
In addition, pubertal LPS treatment does not affect serum testosterone or corticosterone levels in adulthood, suggesting that the observed histological alterations are not a consequence of abnormal hypothalamicpituitary-gonadal or HPA axes activity. Further research is needed to understand the specific role of pubertal LPS treatment on the levels of AR in the prostate and the development and maintenance of prostatic diseases, including cancer $[48,49]$. We conclude that pubertal stress can influence the development of prostatic precancerous lesions in adulthood.

\section{ACKNOWLEDGMENTS}

This study was supported by Consejo Nacional de Ciencia y Tecnología (CONACyT) from Mexico, with a Repatriation grant (CVU-210442 to DHC) and the Natural Sciences and Engineering Research Council of Canada (211075-190799-2001 to NI).

\section{CONFLICTS OF INTEREST}

The authors declare that they have no conflict of interest.

\section{REFERENCES}

1. Williams TH. Occult carcinoma and benign hypertrophy of the prostate in men over fifty years of age. Treat Serv Bull 1954; 9: 201-16.

2. Allott EH, Howard LE, Song HJ, et al. Racial differences in adipose tissue distribution and risk of aggressive prostate cancer among men undergoing radiation therapy. Cancer Epidemiol Biomarkers Prev 2014; 23: 2404-12.

3. Chang SN, Han J, Abdelkader TS, et al. High animal fat intake enhances prostate cancer progression and reduces glutathione peroxidase 3 expression in early stages of TRAMP mice. Prostate 2014; 74: 1266-77.

4. Haque R, Van Den Eeden SK, Wallner LP, et al. Association of body mass index and prostate cancer mortality. Obes Res Clin Pract 2014; 8: e374-81.

5. Roman MD, Niclis C, Tumas N, et al. Tobacco smoking patterns and differential food effects on prostate and breast cancers among smokers and nonsmokers in Cordoba, Argentina. Eur J Cancer Prev 2014; 23: 310-8.

6. Mearini L, Zucchi A, Nunzi E, et al. Low serum testosterone levels are predictive of prostate cancer. World J Urol 2013; 31: 247-52.

7. Sfanos KS, De Marzo AM. Prostate cancer and inflammation: the evidence. Histopathology 2012; 60: 199-215.

8. Herrera-Covarrubias D, Tecamachaltzi-Silvaran MB, Barradas-Moctezuma M, et al. Effect of copulation on potentially precancerous prostate lesions, serum testosterone and prolactin levels in rats. Exp Oncol 2016; 38: 73-9.

9. Agoulnik IU, Krause WC, Bingman WE $3^{\text {rd }}$, et al. Repressors of androgen and progesterone receptor action. $\mathbf{J}$ Biol Chem 2003; 278: 31136-48.

10. Noble RL. Sex steroids as a cause of adenocarcinoma of the dorsal prostate in $\mathrm{Nb}$ rats, and their influence on the growth of transplants. Oncology 1977; 34: 138-41.

11. Herrera-Covarrubias D, Coria-Avila GA, ChavarriaXicotencatl $\mathrm{P}$, et al. Long-term administration of prolactin or testosterone induced similar precancerous prostate lesions in rats. Exp Oncol 2015; 37: 13-8.

12. McCormick CM, Mathews IZ, Thomas C, et al. Investigations of HPA function and the enduring consequences of stressors in adolescence in animal models. Brain Cogn 2010; 72: 73-85. 
13. Romeo RD, Bellani R, Karatsoreos IN, et al. Stress history and pubertal development interact to shape hypothalamic-pituitary-adrenal axis plasticity. Endocrinology 2006; 147: $1664-74$.

14. Almeida SA, Petenusci SO, Franci JA, et al. Chronic immobilization-induced stress increases plasma testosterone and delays testicular maturation in pubertal rats. Andrologia 2000; 32: 7-11.

15. Freeman ME, Kanyicska B, Lerant A, et al. Prolactin: structure, function, and regulation of secretion. Physiol Rev2000; 80: 1523-631.

16. Laugero KD, Moberg GP. Effects of acute behavioral stress and LPS-induced cytokine release on growth and energetics in mice. Physiol Behav 2000; 68: 415-22.

17. Kentner AC, McLeod SA, Field EF, et al. Sexdependent effects of neonatal inflammation on adult inflammatory markers and behavior. Endocrinology 2010; 151: 2689-99.

18. Cai KC, van Mil S, Murray E, et al. Age and sex differences in immune response following LPS treatment in mice. Brain Behav Immun 2016; 58: 327-37.

19. Laroche J, Gasbarro L, Herman JP, et al. Enduring influences of peripubertal/adolescent stressors on behavioral response to estradiol and progesterone in adult female mice. Endocrinology 2009; 150: 3717-25.

20. Olesen KM, Ismail N, Merchasin ED, et al. Long-term alteration of anxiolytic effects of ovarian hormones in female mice by a peripubertal immune challenge. Horm Behav 2011; 60: $318-26$.

21. Ismail N, Kumlin AM, Blaustein JD. A pubertal immune challenge alters the antidepressant-like effects of chronic estradiol treatment in inbred and outbred adult female mice. Neuroscience 2013; 249: 43-52.

22. Ismail N, Blaustein JD. Pubertal immune challenge blocks the ability of estradiol to enhance performance on cognitive tasks in adult female mice. Psychoneuroendocrinology 2013; 38: 1170-7.

23. SAGARPA. Norma Oficial Mexicana NOM-062ZOO-1999, 1999. Available from: http://www.gob.mx/senasica/documentos/nom-062-zoo-1999.

24. CIOMS. International guiding principles for biomedical research involving animals, 1985. Available from: http://www.cioms.ch/publications/guidelines/1985_texts_of_guidelines.htm.

25. Antonio-Cabrera E, Paredes RG. Effects of chronic estradiol or testosterone treatment upon sexual behavior in sexually sluggish male rats. Pharmacol Biochem Behav 2012; 101: 336-41.

26. Stratton LG, Ewing LL, Desjardins C. Efficacy of testosterone-filled polydimethylsiloxane implants in maintaining plasma testosterone in rabbits. J Reprod Fertil 1973; 35: 235-44.

27. Webster M, Witkin KL, Cohen-Fix O. Sizing up the nucleus: nuclear shape, size and nuclear-envelope assembly. J Cell Sci 2009; 122: 1477-86.

28. Zink D, Fischer AH, Nickerson JA. Nuclear structure in cancer cells. Nat Rev Cancer 2004; 4: 677-87.

29. He S, Dunn KL, Espino PS, et al. Chromatin organization and nuclear microenvironments in cancer cells. J Cell Biochem 2008; 104: 2004-15.

30. Grossmann ME, Huang H, Tindall DJ. Androgen receptor signaling in androgen-refractory prostate cancer. J Natl Cancer Inst 2001; 93: 1687-97.
31. Pertschuk LP, Zava DT, Gaetjens E, et al. Detection of androgen and estrogen receptors in human prostatic carcinoma and hyperplasia by fluorescence microscopy. Res Commun Chem Pathol Pharmacol 1978; 22: 427-30.

32. Webber M. Polypeptide hormones and the prostate. In: The prostate cell: structure and function. GP Murphy, AA DSandberg, JP Karr, Eds. Liss: New York, 1981: 63-88.

33. Harper ME, Peeling WB, Cowley T, et al. Plasma steroids. Acta Endocrinol (Copenh) 1976; 81: 409-26.

34. Saroff J, Kirdoni RY, Chu TM, et al. Measurements of prolactin and androgens in patients with prostatic disease. Oncology 1980; 37: 46-52.

35. De la Roca-Chiapas JM, Barbosa-Sabanero G, Martinez-Garcia JA, et al. Impact of stress and levels of corticosterone on the development of breast cancer in rats. Psychol Res Behav Manag 2016; 9: 1-6.

36. Hackett RA, Hamer M, Endrighi R, et al. Loneliness and stress-related inflammatory and neuroendocrine responses in older men and women. Psychoneuroendocrinology 2012; 37: 1801-9.

37. Engler H, Benson S, Wegner A, et al. Men and women differ in inflammatory and neuroendocrine responses to endotoxin but not in the severity of sickness symptoms. Brain Behav Immun 2016; 52: 18-26.

38. Afrasiabi K, Zhou YH, Fleischman A. Chronic inflammation: is it the driver or is it paving the road for malignant transformation? Genes Cancer 2015; 6: 214-9.

39. Walker AK, Hiles SA, Sominsky L, et al. Neonatal lipopolysaccharide exposure impairs sexual development and reproductive success in the Wistar rat. Brain Behav Immun 2011; 25: 674-84.

40. Bierhaus A, Wolf J, Andrassy M, et al. A mechanism converting psychosocial stress into mononuclear cell activation. Proc Natl Acad Sci USA 2003; 100: 1920-5.

41. Dennis LK, Lynch CF, Torner JC. Epidemiologic association between prostatitis and prostate cancer. Urology 2002; 60: 78-83.

42. Sarma AV, McLaughlin JC, Wallner LP, et al. Sexual behavior, sexually transmitted diseases and prostatitis: the risk of prostate cancer in black men. J Urol 2006; 176: 1108-13.

43. Brede CM, Shoskes DA. The etiology and management of acute prostatitis. Nat Rev Urol 2011; 8: 207-12.

44. Cai T, Mazzoli S, Meacci F, et al. Epidemiological features and resistance pattern in uropathogens isolated from chronic bacterial prostatitis. J Microbiol 2011; 49: $448-54$.

45. Boehm BJ, Colopy SA, Jerde TJ, et al. Acute bacterial inflammation of the mouse prostate. Prostate 2012; 72: $307-17$.

46. Elkahwaji JE, Hauke RJ, Brawner CM. Chronic bacterial inflammation induces prostatic intraepithelial neoplasia in mouse prostate. Br J Cancer 2009; 101: 1740-8.

47. Hernandez ME, Soto-Cid A, Aranda-Abreu GE, et al. A study of the prostate, androgens and sexual activity of male rats. Reprod Biol Endocrinol 2007; 5: 11.

48. Walker AM. Prolactin receptor antagonists. Curr Opin Investig Drugs 2005; 6: 378-85.

49. Gonzalez-Lucano LR, Munoz-Valle JF, AscencioCedillo R, et al. Increased expression of the prolactin receptor is associated with malignant laryngeal tumors. Exp Ther Med 2012; 3: 603-7. 